Agro-Science Journal of Tropical Agriculture, Food, Environment and Extension Volume 10 Number 3 Sentember 2011 nn $43-48$

ISSN 1119-7455

\title{
IMPACT OF FADAMA II PROJECT ON RURAL LIVELIHOODS WELL- BEING IN NIGER STATE, NIGERIA
}

\author{
Muhammad, ${ }^{1}$ H. U. Umar, ${ }^{2}$ B .F Abakar, $^{2}$ B.Z. Abdullahi ${ }^{3}$ A .S \\ ${ }^{1}$ Department of Agricultural Economics and Extensions Technology, Federal University of \\ Technology, Minna. \\ ${ }^{3}$ Department of Agricultural Economics and Extension, Faculty of Agriculture Danfodiyo \\ University, Sokoto. \\ ${ }^{4}$ Department of Economics, Usmanu Danfodiyo University, Sokoto, Nigeria.
}

\begin{abstract}
The study assessed the impact of Fadama II project on rural livelihoods well-being in Niger state. Three (Local Government Areas) (LGAs) out of 11 LGAs that benefited from Fadama II project and three LGAs that did not benefit in the project were randomly selected for the study. One Fadama Community Association (FCA) and five Fadama Users`groups (FUGs) were randomly selected from each LGA. Five beneficiaries were also randomly sampled from each FUG. Also simple random sampling procedure was applied to select non-beneficiaries. Seventy five beneficiaries and seventy five non- beneficiaries were randomly sampled, making a total of 150 respondents. Descriptive statistics and paired t-test were used to analyze the data. The results revealed that Fadama II project beneficiaries lived in fairly better houses and owned better means of transportation when compared to non-beneficiaries. On the value of selected assets, housing had the highest value for all the respondents. The mean value of beneficiaries was $\$ 565$, 791, while nonbeneficiaries was $\$ 55,760(P<0.01)$. The mean annual income of the beneficiaries was $\$ 187,726.64$ while the non- beneficiaries had $\$ 48,486.67$ (P<0.05). The study affirmed that Fadama II project impacted positively on the well being of beneficiaries.
\end{abstract}

Keywords: Fadama II project, Community-driven development, Beneficiaries, Nonbeneficiaries, Well-being.

\section{INTRODUCTION}

The major occupation of over $70 \%$ of the rural populace in Nigeria is agriculture. Available records show that most of them are small scale farmers who need assistance to inputs to improve their livethhood (Adebisi and Olalekan, 2004). The rural populace is characterised by low socio-economic status and poor living conditions evident in improper sanitation, lack of access to medical facilities, use of crude tools, low income and low or absence of formal education. There socio econo mic factors had constrained these rural dweller from living above the low income threshold (Mundi, 2000).

However, world Bank-assisted second National Fadama Development Project (Fadama II project) was aimed at delevating the socioeconomic status of the rural dewellers and consequently their income and standard of living. It was a follow up to the first National Fadama Development Project (Fadama I project) that was implemented between 1993-1999. According to Ephraim et al. (2008), Fadama II project was the largest agricultural project in Nigeria that sought to address the noted weakness in the design and implementation of Fadama I Project. These weaknesses included; lack of support to marketing infrastructure, nonparticipation of target beneficiaries in identification and implementation of development projects, gender bias and nonimprovement in management of natural resources.

Consequently, Fadama II project approach shows a shift from public resources domination to a community-driven development (CDD) approach. The CDD approach adopted by Fadama II project enables all users of fadama resources to develop participatory and socially inclusive local development plans (LPDs). The project activities centred on fadama user groups (FUGs) and fadama community association (FCAs). An FUG comprises of fadama users with common economic interest groups (EIGs) and FCA is an association of FUGs that operate in a given area. Twelve states benefited from the projects. By and large, actual implementation of the project only became effective in September, 2005. The Fadama II project had five components namely; capacity building, rural infrastructure, pilot productive assets acquisition 
support, demand responsive advisory services and project management, monitoring and evaluations. Under the pilot productive assets acquisition support, it was required that beneficiaries paid $30 \%$ and $10 \%$ of asset to be acquired and cost of construction infrastructive, respetively. The major objectives of Fadama II project included to support the provision of marketing infrastructure, encourage stakeholders' participation, improve mechanism of conflict resolution, establishment of rural nonfarm enterprise and sustain increase in the income of beneficiaries by at least $20 \%$. The project was implemented from (month) 2005 to (month) 2006 in Nigeri state. It is against this background that, this study attempted to examine the impact of the project in improving the wellbeing of its beneficiaries.

\section{Objectives of the Study}

The general objective of the study was to assess the impact of Fadama II project on well-being of beneficiaries in Niger state.

The specific objectives are to; describe the socio economic characteristics of the respondents, compare the type of house owned by the beneficiaries with that of non-beneficiaries, compare the means of transportation of the beneficiaries with that of non-beneficiaries and compare the value of some selected assets of the beneficiaries with that of non- beneficiaries.

\section{Hypothesis}

Ho: there is no significant difference in income level of Fadama II project beneficiaries and that of non- beneficiaries.

\section{MATERIALS AND METHODS}

The study was conducted in Niger state. The state is located in the Guinea Savannah region in the north central part of Nigeria, between latitude $8^{0}-10^{0} \mathrm{~N}$ and longitudes $3{ }^{0}-8^{0} \mathrm{E}$ with an estimated total land area of 74,244 square kilometres. (Misari,2002). estimated total human population 3,950,249 (NPC, 2007).
The major ethnic groups of the state are Nupe, Gbagyi and Hausa with farming as their occupation. The state experiences distinct wet and dry seasons with mean annual rainfall between 1000-1500mm.

A list of fadama II project beneficiaries in the state was obtained from the Niger State National Second Fadama Development Project (NGSNSFDP) Office. A multi stage random sampling was adopted in the study. To obtain the sample size of the Fadama II Project beneficiaries; Stage 1: Random selection of three out of 11 LGAs that benefited. Stage 2: Random selection of one fadama community association (FCA) from each of the selected LGAs. Stage 3: Five fadama user groups (FUGs) were randomly selected from each of the FCA and Stage 4: Random selection of five household heads from each of the FUGs. A total of 75 beneficiaries were randomly selected to take part in the study. However, to obtain the population of nonbeneficiaries that participated in the study; Stage 1: Random selection of three non-benefiting LGAs, this was in order to avoid spill over effect. Stage 2: Random selection of one district from each LGA. Stage 3: Five villages were randomly selected from each district. Stage 4: Random selection of five household heads from each village. A total of 75 non-beneficiaries were also randomly selected. Structured questionnaire was administered to the respondents by trained enumerators. The data obtained was subjected to descriptive and paired t-test statistics.

The choice of paired t-test was based on similar study which assessed the impact of selected rural development programmes on poverty alleviation as well as a paper that compared crop output, farm income, farm size and labour of fadama and non-fadama farmers (Ezeh,2004; Nwachukwu and Ezeh,2007).

The assets were valued at market price (i.e. naira worth for each of the assets at the time of this study). 


\section{RESULTS AND DISCUSSION}

Demographic characteristics

The gender distribution in Table 1 reveals that majority $(72.0 \%$ and $88.0 \%)$ were male beneficiaries and non- beneficiaries respectively. Thus female participation was low. Majority $(54.7 \%)$ of the beneficiaries were within the age range of $45-59$ years while $45.3 \%$ of the nonbeneficiaries were within the same age bracket. Both the youth, and elderly benefited in Fadama II project. Also majority $(66.7 \%$ and $89.3 \%)$ of the beneficiaries and non -beneficiaries were married respectively. Results in Table1 also show that $45.33 \%$ of the beneficiaries possessed primary school education while $24.0 \%$ had secondary school education. About $21.3 \%$ of the beneficiaries had no formal education while $36.0 \%$ and $14.67 \%$ of the non- beneficiaries possessed primary and secondary school education, respectively. This implies there was higher literacy level among the beneficiaries than the non-beneficiaries and this was likely to bring about disparity in their levels of understanding of a programme and productivity. This is in line with Osun (2001) who opined that higher level of education attained by an individual not only increases his productivity but also enhances his ability to understand and utilize new technologies. Results in Table1 also reveal that majority $(60.0 \%)$ of both beneficiaries and non-beneficiaries were farmers. This substantiates the view of Yisa $e t$ al. (2010) that rural areas are the food basket of the nation. However, both the beneficiaries and non-beneficiaries in the study area were found to engage in other occupations like trading and knitting but to less extent. The results also reveal that $45.3 \%$ of the beneficiaries and $41.3 \%$ of the non-beneficiaries had household size of between 11-15 persons per household and the mean household size for both the beneficiaries and non-beneficiaries was 8 and 7 persons, respectively. This large household size depicts characteristics of rural households in northern Nigeria where polygamy is mostly practiced. This finding is in line with Yisa et al. (2010) that farmers in the rural areas are predominantly large families.

Results also show that majority $(70.7 \%)$ of the beneficiaries had 3-4 years cooperative membership experience but most $(60.0 \%)$ of the non-beneficiaries had less than one year cooperative experience. This implies that cooperative society is not new among the beneficiaries.

\section{Type of Housing}

Results in Table 2 revealed that majority $(69.3 \%)$ of the beneficiaries owned wood/mud zinc roof type of housing while $60.0 \%$ of the non-beneficiaries lived in wood/mud thatched roof type of housing. It implies that majority of the beneficiaries live in fairly better houses than the non-beneficiaries; this could be attributed to Fadama II project intervention they enjoyed.

\section{Means of Transportation}

Results in Table 3 show that majority $(64.0 \%)$ of the beneficiaries owned motorcycles while $467 \%$ of the non-beneficiaries had bicycle as major means of transportation. Also some of the beneficiaries owned buses and pick-up vans while the non- beneficiaries had neither buses nor pick-up vans (Table 3). The results suggest that the beneficiaries have better means of transportation than the non beneficiaries. This could be attributed to lower acquisition capability of the non-beneficiaries that is informed by their poor income level 
Table 1: Socio-economic characteristics of the respondents

\begin{tabular}{|c|c|c|c|c|}
\hline Variables & Beneficiaries frequency & $\%$ & Non-beneficiaries frequency & $\%$ \\
\hline \multicolumn{5}{|l|}{ Gender } \\
\hline Male & 54 & 72.0 & 66 & 88.0 \\
\hline \multirow[t]{2}{*}{ Female } & 21 & 28.0 & 9 & 12.9 \\
\hline & 75 & 100 & 75 & 100 \\
\hline \multicolumn{5}{|l|}{ Age group (yrs) } \\
\hline Less than 30 & 2 & 2.6 & 6 & 8.0 \\
\hline $30-44$ & 20 & 26.7 & 27 & 36.0 \\
\hline $45-59$ & 41 & 54.7 & 34 & 45.3 \\
\hline \multirow[t]{2}{*}{60 and above } & 12 & 16.0 & 8 & 10.7 \\
\hline & 75 & 100 & 75 & 100 \\
\hline \multicolumn{5}{|l|}{ Marital status } \\
\hline Married & 59 & 66.7 & 67 & 89.3 \\
\hline Widow & 10 & 13.3 & 4 & 5.3 \\
\hline Single & 8 & 10.7 & 2 & 2.7 \\
\hline \multirow[t]{2}{*}{ Divorced } & 7 & 9.3 & 2 & 2.7 \\
\hline & 75 & 100 & 75 & 100 \\
\hline \multicolumn{5}{|l|}{ Educational Status } \\
\hline Non formal & 16 & 21.3 & 37 & $49 . .40$ \\
\hline Primary & 34 & 45.3 & 27 & 36.0 \\
\hline Secondary & 18 & 24.0 & 11 & 14.7 \\
\hline \multirow[t]{2}{*}{ Tertiary } & 7 & 9.3 & - & - \\
\hline & 75 & 100 & 75 & 100 \\
\hline \multicolumn{5}{|l|}{ Occupation } \\
\hline Farming & 45 & 60.0 & 460 & 61.3 \\
\hline trading & 7 & 9.3 & 6 & 8.0 \\
\hline Artisanship & 3 & 4.0 & 11 & 14.7 \\
\hline Civil servant & 11 & 14.7 & 3 & 4.0 \\
\hline \multirow[t]{2}{*}{ Others } & 9 & 12.0 & 9 & 12.0 \\
\hline & 75 & 100 & 75 & 100 \\
\hline \multicolumn{5}{|c|}{ Household size (no of persons) } \\
\hline $1-5$ & 3 & 4.0 & 9 & 12.0 \\
\hline $6-10$ & 18 & 24.0 & 17 & 22.0 \\
\hline $11-15$ & 34 & 45.3 & 30 & 40.0 \\
\hline \multirow[t]{2}{*}{ Above 15} & 20 & 26.7 & 19 & 25.0 \\
\hline & 75 & 100 & 75 & 100 \\
\hline \multicolumn{5}{|c|}{ Cooperative Membership (yrs) } \\
\hline Less than 1 years & - & - & 45 & 60.0 \\
\hline $1-2$ & 3 & 4.0 & 13 & 173 \\
\hline $3-4$ & 53 & 70.7 & 11 & 14.7 \\
\hline \multirow[t]{2}{*}{ Above 4} & 19 & 25.3 & 6 & 8.0 \\
\hline & 75 & 100 & 75 & 100 \\
\hline
\end{tabular}

Source: Field Survey, 2009.

Table 2: Type of House Owned

\begin{tabular}{lllll}
\hline Household type & Beneficiaries & $\%$ & $\begin{array}{l}\text { Non- beneficiaries } \\
\text { Frequency }\end{array}$ & $\%$ \\
Wood/ mud thatched roof & 5 & 6.7 & 45 & 60.0 \\
Wood/mud zinc roof & 52 & 69.3 & 28 & 37.3 \\
Cement block brick with zinc & 18 & 24.0 & 2 & 2.7 \\
\hline
\end{tabular}

Source: field survey, 2009 


\section{Values of Selected Assets}

Results of paired t-test (Table 4) show that house asset had the highest value for all the respondents. The beneficiaries house had mean value of N565,791 while that of nonbeneficiaries had N55,760. The difference in the mean value of Fadama II Project beneficiaries and non-beneficiaries' house was found to be statistically significant at $\mathrm{P}<0.01$ level. This affirms that beneficiaries have fairly better houses than the non- beneficiaries. Mean value for means of transportation for the beneficiaries was N82,911 and non-beneficiaries had N31,197 and statistically significant at $\mathrm{P}<0.05$. This reveals that beneficiaries have better means of transportation than the non-beneficiaries; this may be attributed to Fadama II project intervention they received. Similarly, the mean value of household items and livestock for the beneficiaries were N22,374 and N88,533 while non- beneficiaries had N18,803 and N37,716, respectively and statistically significant at $\mathrm{P}<$ 0.05 , which further affirms that the beneficiaries possessed more of the household items and livestock than the non-beneficiaries, this may also be attributed to Fadama II project intervention. However, farm assets had least value for all the respondents. But the mean values for beneficiaries and non-beneficiaries was statistically significant at $\mathrm{P}<0.05$ level. The farm assets owned by the beneficiaries was valued at $\$ 14,047$ while similar farm assets for the non-beneficiaries was valued at $\mathrm{N} 4,187$. These low values may be because not all the respondents were engaged in farming. However, results of paired t-test affirmed that the values of selected assets owned by the beneficiaries were generally statistically significant from that of non- beneficiaries in the study area.

Table 3: Respondents` ownership of means of transportation

\begin{tabular}{lllll}
\hline Transportation means & Beneficiaries frequency & \% & Non- beneficiaries frequency & \% \\
\hline Bicycle & 9 & 12.0 & 35 & 46.7 \\
Motorcycle & 48 & 64.0 & 20 & 26.7 \\
Bus & 5 & 6.7 & - & - \\
Pick van & 5 & 6.7 & - & - \\
Donkey & 6 & 8.0 & 12 & 16.0 \\
None & 2 & 2.7 & 8 & 10.9 \\
& 75 & 100 & 75 & 100 \\
\hline
\end{tabular}

Source: field survey, 2009

Table 4: Value of selected assets of respondents

\begin{tabular}{llll}
\hline Assets type & Respondents & Mean value of assets N & t- value \\
\hline House & Beneficiaries & 56591 & $6.365^{* *}$ \\
& & $(56904)$ & \\
& Non- beneficiaries & 55760 & $3.917^{* *}$ \\
Means of transportation & Beneficiaries & 82911 & \\
& Non-beneficiaries & 31197 & $4.240^{* *}$ \\
Household items & $(332)$ & \\
& Beneficiaries & 22376 & \\
& Non- beneficiaries & $(2042)$ & $2.457^{* *}$ \\
Livestock & & 18803 & \\
& & $(402)$ & $5.253^{* *}$ \\
Farm equipment & Beneficiaries & 88533 & \\
& Non-beneficiaries & 37916 & $(4279)$ \\
& & 14047 & \\
& Beneficiaries & $(26.11)$ & \\
& & & \\
& Non-beneficiaries & $(187)$ & \\
\hline
\end{tabular}

Source: field survey, 2009

** Significant at $5 \%$ level

*** Significant at $1 \%$ level

Figures in parentheses are standard deviations

Table 5: Mean annual income of respondents

\begin{tabular}{llll}
\hline Type of respondents & Mean annual income & $\mathbf{N}$ & t- value \\
\hline Beneficiaries & $187,726.64(1211916)$ & & $9.98^{* * *}$ \\
Non beneficiaries & $48,486.67(2292.55)$ & & \\
\hline Sources: field survey, 2009 & & \\
** Significance at 5\% level & & \\
Figures in parentheses are standard deviations &
\end{tabular}


Impact of Fadama II Project on Rural Livelihoods

\section{Hypothesis testing}

The results of t-test in Table 5 revealed the difference in annual mean income of the respondents. The mean annual income for the beneficiaries was $\$ 187,726.64$ and the nonbeneficiaries has $\$ 48,486.67$ while the mean difference was $\$ 139,239.97$. The difference in the mean annual income of Fadama II Project beneficiaries and non-beneficiaries was statistically significant $(\mathrm{P}<0.05)$. The null hypothesis of no significant difference in income level of Fadama II project beneficiaries and that of non- beneficiary was rejected.

\section{CONCLUSION}

The results obtained from the study revealed that the intervention of Fadama II project in the study area impacted positively on the general well being or livelihood of the beneficiaries. Consequently analysis of value of some selected assets owned by both beneficiaries and nonbeneficiaries revealed that the value of assets of the beneficiaries were higher than that of nonbeneficiaries. Also, the mean annual earnings of the beneficiaries was found to be statically significant while compared to that of the nonbeneficiaries, implying that Fadama II project impacted positively on the livelihood of its beneficiaries.

\section{REFERENCES}

Adebisi, A. and R.Y Olalekan (2004). Cooperation and poverty alleviation in rural settlement of Kwara state, Nigeria. Nigerian Journal of Savannah, 19(2): 123-125

Ephraim, N.P. Dayo, O. Adetunji, M. Tewodaj, K.Y. Mohammed, A.Gbenga, P. John, A. Tunji, I. Frank and K. Edward (2008). From the ground up impacts of a pro-poor community driven development project in Nigeria IFPRI Discussion paper 00756. $\mathrm{Ppl}-23$

Ezeh, C.I. (2004). A comparative study of fadama and non-fadama crop farmers in
Osisioma-Ngwa Local Government Area, Abia State, Nigeria. Journal of Tropical and Sustainable Agriculture. Vol. 13: 31-35.

Misari, S. (2002). Rice research programme report in annual review meetings $25^{\text {th }}-$ $28^{\text {th }}$ June.

Mundi, N.E. (2000). The role of women in poverty alleviation in Nigeria. African Journal of Economics and Society 2(2): 71-73

National Population Commission (NPC) (2007). Federal republic of Nigeria, Official Gazette. 94(24).

Nwachukwu, I.N. and Ezeh,C.I. (2007). Impact of Selected Rural Development Programmes on Poverty Alleviation in Ikwano Local Government Area, Abia State.http://www.bioline.org.br/request ? Nd07042. Accessed 25/08/2008

Osun, T. (2001). Analysis of socio economic factors affecting cocoa production in Ondo State : case study of Idanre East Local Government Area, Ondo State unpublished undergraduate project report, Department of Agricultural Economics and Extensions, Federal University of Technology, Akure, Nigeria

Yisa, E.S., A. Ogaje, O.J. Ajayi, T. LikiTa and A.Shaffi (2010). Assessment of the effect of agricultural productivity in rural household food security in Katcha Local Government Area, Niger State. In: J.N Nmadu, M.A. Ojo, U.S Mohammed, K.M Baba, F.D Ibrahim and E.S Yisa (eds). Commercial Agriculture, Banking Reform and Economic Downturn: Setting a New Agenda for Agricultural Development in Nigeria. Proceeding of $11^{\text {th }}$ Annual National Conference of National Association of Agricultural Economists of Nigeria. Federal University of Technology, Minna. pp 280-281. 